\title{
A comparative study of epiretinal membranes associated with Eales' disease: a clinicopathologic evaluation
}

${ }^{1}$ Smt Kanuri Santhamma Retina-Vitreous Centre, LV Prasad Eye Institute, Hyderabad, India

${ }^{2}$ Saroja Rao Department of Pathology, LV Prasad Eye Institute, Hyderabad, India

${ }^{3}$ Centre for Cellular \& Molecular Biology,

Hyderabad, India

Correspondence: AB Majji, LV Prasad Eye Institute, LV Prasad Marg, Banjara Hills, Hyderabad 500 034, India Tel: + 9104023608 262; Fax: +9104023548271 E-mail: ajit@lvpei.org

Received: 8 September 2004

Accepted in revised form: 21 October 2004

Published online: 29 April 2005

Proprietary interest: None.

This paper was a presentation at ARVO 2002, Fort Lauderdale, FL, USA.
Abstract

Aim To study the histopathologic features and clinical correlation of epiretinal membranes (ERM) obtained from patients of Eales' disease and compare with other vasoproliferative disorders.

Methods Retrospective analysis of epiretinal membranes submitted for histological evaluation between January 1995 and June 2001, from the patients of diabetic retinopathy and vascular occlusions (Group 1; vasoocclusive disorders) and of Eales' disease (Group 2; vasoinflammatory disorders). Demographics, pre and postoperative visual acuity, and anatomic and histologic characteristics of membranes were studied. Histopathologic features and clinical outcomes were correlated between the groups. The results were analysed statistically by Student's $t$-test, Fisher's exact test and Kruskal-Wallis test.

Results This study consisted of 42 patients, 24 in Group 1 and 18 in Group 2. Patients in Group $2(33.0 \pm 9.2$ years) were significantly younger than the patients in Group 1 (49.9 \pm 7.6 years) $(P \leq 0.0001)$. Final visual acuity of $>20 / 400$ was attained in $79.2 \%(19 / 24)$ patients in Group 1 and $83.3 \%$ (15/18) in Group $2(P=1.0)$. Inflammatory membranes were significantly associated with presumed Eales' disease $(94.4$ vs $0 \%)(P \leq 0.0001)$ and fibrovascular membranes with Group $1 \mathbf{( 7 0 . 8 \%}$ vs $33.3 \%)(P=0.028)$. Mast cells and eosinophils were observed as special features in epiretinal membranes of patients with Eales' disease.

Conclusions Histological features of ERM in Eales' disease are comparable to other
AB Majji', GK Vemuganti², VA Shah ${ }^{1}$, S Singh ${ }^{3}$, T Das ${ }^{1}$ and S Jalali' vasoproliferative disorders except for features of inflammation. Presence of mast cells and eosinophils in epiretinal membranes of Eales' disease needs further investigation.

Eye (2006) 20, 46-54. doi:10.1038/sj.eye.6701788; published online 29 April 2005

Keywords: epiretinal membrane; histology; idiopathic retinal vasculitis; Eales' disease; diabetic retinopathy; vascular occlusion

\section{Introduction}

Eales' disease, first described by Henry Eales in 1882 , is a primary perivasculitis that predominantly affects the peripheral retina of young and otherwise healthy adults in the age group of $20-40$ years. ${ }^{1-10}$ It is regarded as a clinical syndrome presenting with retinal perivasculitis affecting the peripheral retina (inflammatory stage), resulting in sclerosis of the retinal vessels (obliterative stage) and finally retinal neovascularization and recurrent vitreous haemorrhage (ischaemic stage), with or without retinal detachment (angiogenesis/ proliferative stage). ${ }^{5,6,8,10}$ The treatment strategies involve oral corticosteroids in the inflammatory stage, photocoagulation in the ischaemic stage, and vitrectomy and epiretinal membrane (ERM) removal with additional procedures in the proliferative stage. ${ }^{5,6} \mathrm{ERMs}$, in general, are the result of proliferation and differentiation of different cell types. They include retinal pigment epithelium (RPE) and retinal glial cells in proliferative vitreoretinopathy (PVR), vascular endothelium, fibroblasts, and macrophages in retinal vasoproliferative disorders such as diabetic 
retinopathy and vascular occlusions and blood cellular components in inflammatory disorders. ${ }^{11-30}$

Aetiopathogenesis of Eales' disease is not well understood because of lack of appropriate specimen for microbiology and histopathology studies. The availability of tissue specimen in active stages of the disease is quite unlikely because it is a disease of young healthy persons and involves the retinal periphery in its early stages. Hence, ERMs obtained from the patients of Eales' disease, who need vitrectomy for nonresolving vitreous haemorrhage or other sequel of proliferative stages, are the most appropriate for such studies. ${ }^{7}$ The ERMs obtained from Eales' disease are fibrovascular in nature and are similar to those in other vasoproliferative disorders like diabetic retinopathy and vascular occlusions. $^{7}$

In this study, we evaluated the histopathologic features of ERMs obtained from patients of idiopathic vasculitis of presumed Eales' disease and were compared with the ones from vaso-occlusive disorders like diabetes and vascular occlusions. To determine the clinical significance and to understand the pathogenesis of ERMs in Eales' disease, the morphologic features were correlated with the clinical features.

\section{Methods}

The epiretinal membranes obtained during vitrectomy between January 1995 and June 2001 were evaluated. We included patients of diabetes and vascular occlusions with ERMs as vaso-occlusive disorders (Group 1) and idiopathic retinal vasculitis of presumed Eales' disease as vasoinflammatory disorder (Group 2) for evaluation and comparison. A diagnosis of presumed Eales' disease was made if the patient had unilateral or bilateral obliterative retinal vasculitis affecting the veins without a known and definitive cause (Figure 1a-c). The systemic work-up of the patient included peripheral blood smear, erythrocyte sedimentation rate, blood chemistry including blood sugar, Mantoux, chest radiography, specific tests for syphilis, test for human immunodeficiency virus, and collagen vascular disorders. A diagnosis of proliferative diabetic retinopathy was made in patients with history of raised blood sugar levels along with fundus and angiographic evidence of microaneurysms, capillary nonperfusion, and fibrovascular proliferative membranes in either or both eyes. Vascular occlusions were diagnosed by the distribution of the retinal haemorrhages or soft exudates in the distribution of the retinal vessels, in the absence of any overlying inflammatory cells or vascular cuffing.

We excluded patients in whom the ERMs were obtained for diagnoses other than diabetic retinopathy, vascular occlusions, and Eales' disease. We also excluded the patients with incomplete data or inadequate followup, ERMs obtained during second surgical intervention or those obtained from silicone oil-filled eyes, even if they bear a diagnosis of diabetic retinopathy, venous occlusions, or Eales' disease.

Patient demographic data included detailed history of duration of decrease in vision (which might reflect the duration of ERM), past treatment, associated systemic illness and systemic work-up (including all the tests as mentioned earlier). Ocular evaluation included slit-lamp biomicroscopy, applanation tonometry, indirect ophthalmoscopy, ultrasonography, fundus fluorescein angiography, best corrected visual acuity, details of the surgery, location and nature of membrane, and postoperative course including the best corrected visual acuity.

Informed consent was obtained from each patient after explaining the nature of the disease, details regarding surgery and possible consequences of intervention. All patients were operated by standard 3-port pars plana vitrectomy with ERM peeling with or without additional procedures. The ERMs were obtained by using intravitreal forceps either directly or retrieved after they were isolated and dissected from the retinal surface using the horizontal intravitreal scissors. Immediately after taking out of the eye, the membranes were fixed in $2 \%$ glutaraldehyde and $2 \%$ formaldehyde.

The specimens were postfixed for $2 \mathrm{~h}$ in $2 \%$ osmium tetroxide in phosphate buffer, acetone dehydrated and embedded in epoxy resin. Semithin sections were stained with aqueous $0.1 \%$ toluidine blue (Merk) in $1 \%$ borax solution for light microscopy. Ultrathin sections were stained with lead citrate and uranyl acetate and examined in transmission electron microscope (Jeol I00 CX).

The postoperative data included final visual acuity and associated complications. The visual results and the histological type of membranes were compared between the groups. The membranes were divided histologically into: (a) predominantly vascular - wherein the vessels were prominent, lined by clusters of plump endothelial cells, and had proliferating edges, (b) predominantly fibrous - wherein the membrane consisted of dense fibrocollagenous stroma with sparse cellularity and vessels, (c) fibrovascular-consisting of membranes which showed a fibrocellular stroma with few vessels, and (d) inflammatory membranes - wherein the stroma showed inflammatory cells. The cellular components observed in the histological sections were also noted. The predominant cell types were observed. The clinical and histological parameters were compared between the groups with special emphasis on the additional features in patients with presumed Eales' disease. 

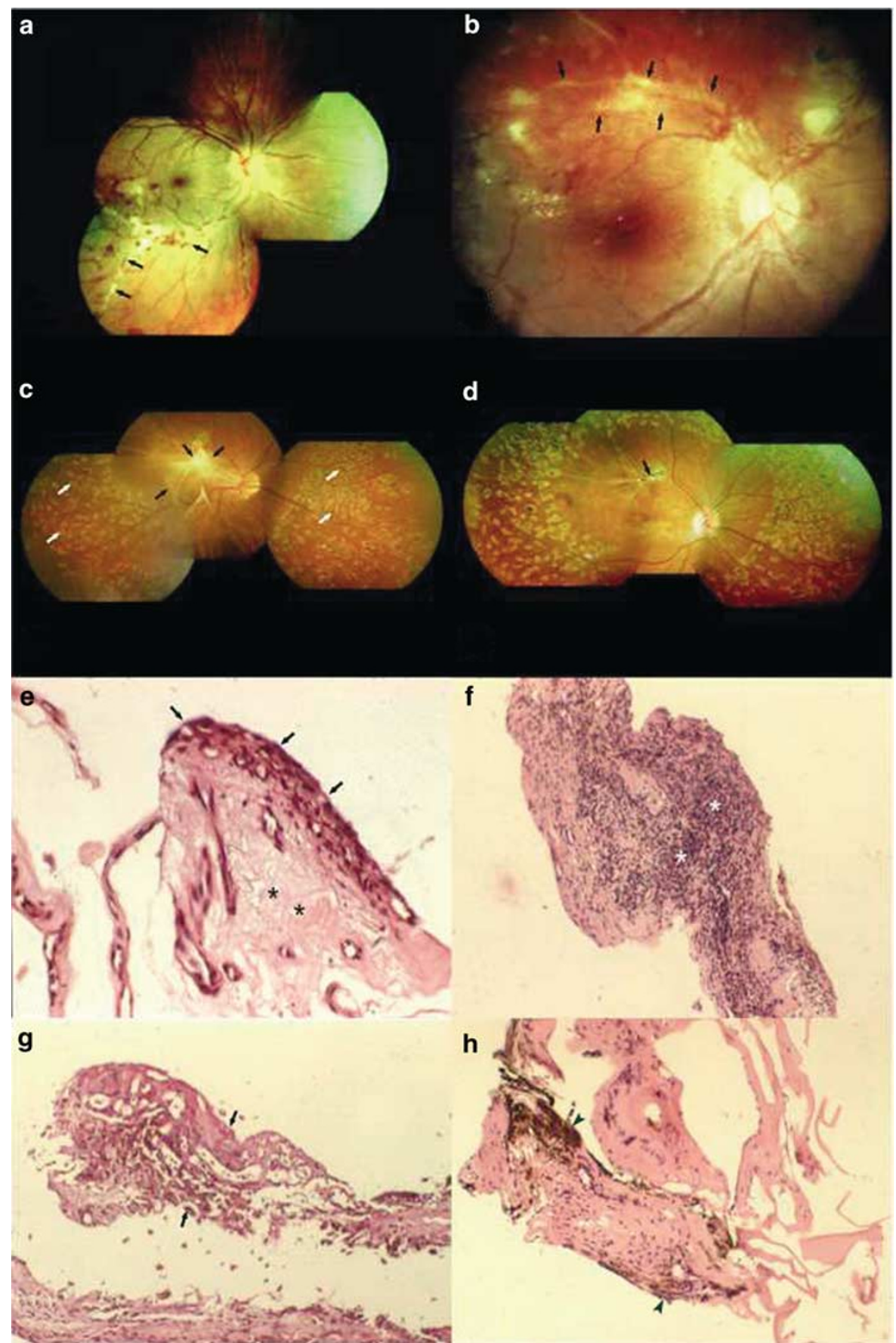

Figure 1 (a-d) Colour fundus photographs of patients with Eales' disease showing: (a) active vasculitis involving the inferotemporal branch retinal vein (black arrows), (b) proliferative stage with predominantly vascular ERM (black arrows) along the superotemporal branch retinal vein, (c) fibrous proliferation (black arrows) involving the macular area with old scatter photocoagulation marks (white arrows) in the retinal periphery, and (d) retina of the same patient as in (c), after removal of ERM. An area of hyperpigmentation (black arrow) corresponds to the origin of ERM. (e-h) Light microscopy photographs showing: (e) vascular growing edge with endothelial buds (black arrows) and sparse collagen (black asterisks) from a patient of diabetic retinopathy (H\&E, $\times 125)$. (f) A predominantly fibrous ERM with abundant lymphocytic infiltration (white asterisks) and collagen from a patient of Eales' disease $(\mathrm{H} \& \mathrm{E}, \times 50)$. (g) A fibrovascular ERM from a patient of Eales' disease, with equal distribution of vascular, fibrocellular and collagen (black arrows) components $(H \& E, \times 125)$. (h) A fibrovascular ERM from a patient of diabetic retinopathy showing scattered pigment (black arrowhead) $(\mathrm{H} \& \mathrm{E}, \times 125)$. 


\section{Statistical analysis}

A two-tailed independent sample $t$-test was performed between the groups for continuous variables, and Fisher's exact test for categorical variables, and the group differences in the proportion of patients achieving a specific acuity level. A nonparametric Kruskal-Wallis test was performed to compare the duration of symptoms between different types of membranes. Analyses were performed by SPSS 11.0 for windows (SPSS Inc, Chicago, USA) software.

\section{Results}

\section{Clinical features}

A total of 5775 primary vitrectomies were performed at the retina-vitreous services of LV Prasad Eye Institute between January 1995 and June 2001. A total of 42 patients were included in the study, who fulfilled the inclusion criteria. In all, 24 patients belong to the clinical subtype of vaso-occlusive disorders (Group 1) and 18 were of vasoinflammatory (Group 2) (Figure $1 \mathrm{~b}-\mathrm{d}$ and Tables 1 and 2). In total, 37 (88.1\%) were men and five
(11.9\%) were women. Of 24 patients, 19 (79.2\%) were men in Group 1 and all 18 patients $(100 \%)$ in Group 2 were men $(P=0.060)$. The age of the patients ranged from 18 to 65 years $(42.6 \pm 11.7$ years). The average age of the patients in Group 1 was $49.9 \pm 7.6$ years compared to $33.0 \pm 9.2$ years in Group $2(P<0.0001, t$-test $)$. A total of 22 patients (52.4\%) had right eye affected and 20 (47.6\%) in left eye. The mean duration of symptoms was 13.8 months (13.6 months in Group 1 and 14.1 months in Group 2). Average follow-up period was 8.8 months in Group 1 and 11.7 months in Group 2. There was no significant difference in the gender, duration of symptoms, and duration of follow-up period between the groups ( $P>0.05$, Fisher's exact test) (Tables 1 and 2$)$.

Final visual acuity of better than 20/400 was observed in 34/42 (81\%) patients among all patients in this study. This was observed in 19 of 24 (79.2\%) patients in Group 1 and 15 of $18(83.3 \%)$ in Group 2. No significant difference in visual outcome was observed between the groups $(P=1.0)$. Of 42 patients, 25 had received cryo/ laser earlier (16 of 24; 66.7\% in Group 1 and nine of 18; $50 \%$ eyes in Group 2) $(P=0.35)$. Visual acuity improvement of better than $20 / 400$ among the patients

Table 1 Histopathologic and clinical details of the patients of group 1 (vaso-occlusive diseases with epiretinal membranes)

\begin{tabular}{|c|c|c|c|c|c|c|c|c|c|c|c|c|c|}
\hline \multirow[t]{2}{*}{$S N o$} & \multirow[t]{2}{*}{ Gender } & \multirow{2}{*}{$\begin{array}{c}\text { Age } \\
\text { (years) }\end{array}$} & \multirow[t]{2}{*}{ Eye } & \multirow[t]{2}{*}{ Diagnosis } & \multirow{2}{*}{$\begin{array}{c}\text { Duration }^{a} \\
\text { (months) }\end{array}$} & \multicolumn{2}{|c|}{ Visual acuity } & \multirow[t]{2}{*}{ Cryo } & \multirow[t]{2}{*}{ Laser } & \multirow{2}{*}{$\begin{array}{l}\text { Location } \\
\text { of ERM }\end{array}$} & \multicolumn{2}{|c|}{ Type of ERM } & \multirow{2}{*}{$\begin{array}{c}\text { Follow-up } \\
\text { (months) }\end{array}$} \\
\hline & & & & & & Pre-op & Post-op & & & & Clinical & Histopath. & \\
\hline 1 & M & 44 & OD & CRVO & 18 & HM & NLP & $\mathrm{N}$ & $\mathrm{Y}$ & Disc & $\mathrm{F}$ & $\mathrm{F}$ & 4 \\
\hline 2 & M & 51 & OS & BRVO & 9 & HM & $20 / 100$ & $\mathrm{~N}$ & $\mathrm{Y}$ & Macula & FV & $\mathrm{F}$ & 6 \\
\hline 3 & $\mathrm{~F}$ & 40 & OD & BRVO & 4 & $20 / 200$ & $20 / 100$ & $\mathrm{~N}$ & $\mathrm{~N}$ & ST & $\mathrm{FV}$ & FV & 5 \\
\hline 4 & $\mathrm{M}$ & 60 & OS & PDR & 36 & $20 / 400$ & $20 / 50$ & $\mathrm{~N}$ & $\mathrm{Y}$ & Disc & $\mathrm{FV}$ & $\mathrm{FV}$ & 16 \\
\hline 5 & $\mathrm{~F}$ & 45 & OD & PDR & 14 & HM & $\mathrm{CF} 1 \mathrm{mt}$ & $\mathrm{N}$ & $\mathrm{Y}$ & Macula & FV & FV & 10 \\
\hline 6 & $\mathrm{M}$ & 60 & OD & PDR & 24 & LP & $20 / 80$ & $\mathrm{Y}$ & $\mathrm{N}$ & M, D & $\mathrm{F}$ & $\mathrm{FV}+$ gr. edge & 10 \\
\hline 7 & $\mathrm{~F}$ & 53 & OD & BRVO & 3 & LP & $20 / 100$ & $\mathrm{~N}$ & $\mathrm{~N}$ & IT & $\mathrm{FV}$ & $\mathrm{F}$ & 14 \\
\hline 8 & $\mathrm{~F}$ & 37 & OD & PDR & 5 & CF $3 \mathrm{mt}$ & $20 / 50$ & $\mathrm{~N}$ & $\mathrm{Y}$ & IT, ST & FV & FV & 46 \\
\hline 9 & $\mathrm{M}$ & 43 & OS & PDR & 7 & $\mathrm{CF} 2 \mathrm{mt}$ & $20 / 30$ & $\mathrm{~N}$ & $\mathrm{~N}$ & $\mathrm{D}$ & FV & $\mathrm{F}$ & 6 \\
\hline 10 & $\mathrm{M}$ & 65 & OS & PDR & 6 & $20 / 100$ & $20 / 400$ & $\mathrm{~N}$ & $\mathrm{Y}$ & M, ST & $\mathrm{F}$ & FV & 6 \\
\hline 11 & M & 50 & OS & PDR & 14 & LP & LP & $\mathrm{N}$ & $\mathrm{N}$ & M, IT & FV & $\mathrm{F}$ & 4 \\
\hline 12 & $\mathrm{M}$ & 44 & OS & PDR & 4 & LP & $20 / 200$ & $\mathrm{~N}$ & $\mathrm{Y}$ & M, ST & FV & FV & 8 \\
\hline 14 & $\mathrm{M}$ & 42 & OD & PDR & 60 & $20 / 400$ & $20 / 50$ & Y & Y & Macula & FV & $\mathrm{V}$ & 6 \\
\hline 15 & $\mathrm{M}$ & 51 & OD & PDR & 8 & HM & $20 / 200$ & $\mathrm{~N}$ & $\mathrm{Y}$ & $\mathrm{D}, \mathrm{M}$ & FV & $\mathrm{V}+$ gr. edge & 13 \\
\hline 16 & M & 43 & OD & PDR & 8 & $20 / 80$ & $20 / 60$ & $\mathrm{~N}$ & $\mathrm{Y}$ & $\mathrm{D}, \mathrm{M}, \mathrm{IT}$ & $\mathrm{F}$ & FV & 5 \\
\hline 17 & M & 45 & OS & BRVO & 13 & $\mathrm{CF} 1 \mathrm{mt}$ & $20 / 100$ & $\mathrm{~N}$ & $\mathrm{~N}$ & D, ST & FV & $\mathrm{F}$ & 6 \\
\hline 18 & M & 65 & OS & BRVO & 18 & LP & $20 / 80$ & $\mathrm{~N}$ & $\mathrm{~N}$ & $\mathrm{D}, \mathrm{ST}$ & FV & FV & 6 \\
\hline 19 & M & 52 & OS & PDR & 6 & LP & $\mathrm{CF} 2 \mathrm{mt}$ & $\mathrm{N}$ & $\mathrm{Y}$ & Macula & FV & FV & 5 \\
\hline 20 & M & 55 & OS & PDR & 10 & LP & $20 / 200$ & $\mathrm{~N}$ & $\mathrm{Y}$ & $\mathrm{D}, \mathrm{M}$ & $\mathrm{FV}$ & $\mathrm{FV}+$ gr. edge & 5 \\
\hline 21 & $\mathrm{M}$ & 58 & OD & BRVO & 8 & HM & $20 / 200$ & $\mathrm{~N}$ & $\mathrm{Y}$ & $\mathrm{D}$ & FV & FV & 4 \\
\hline 22 & M & 51 & OD & BRVO & 2 & $\mathrm{CF} 2 \mathrm{mt}$ & $20 / 60$ & $\mathrm{~N}$ & $\mathrm{~N}$ & $\mathrm{D}, \mathrm{ST}$ & $\mathrm{F}$ & FV & 6 \\
\hline 23 & $\mathrm{M}$ & 48 & OS & PDR & 36 & LP & $20 / 400$ & $\mathrm{~N}$ & $\mathrm{Y}$ & $\mathrm{D}, \mathrm{ST}$ & FV & FV & 4 \\
\hline 24 & $\mathrm{M}$ & 50 & OD & PDR & 3 & $20 / 25$ & $20 / 25$ & $\mathrm{~N}$ & $\mathrm{Y}$ & D, ST & FV & FV & 6 \\
\hline
\end{tabular}

$\mathrm{M}=$ male; $\mathrm{F}=$ female; $\mathrm{OD}=$ right eye; $\mathrm{OS}=$ left eye; $\mathrm{PDR}=$ proliferative diabetic retinopathy; $\mathrm{CRVO}=$ central retinal vein occlusion; $\mathrm{BRVO}=$ branch retinal vein occlusion; $\mathrm{HM}=$ hand movements; $\mathrm{NLP}=$ No light perception; $\mathrm{LP}=$ light perception; $\mathrm{CF}=\mathrm{counting}$ fingers; $\mathrm{N}=\mathrm{No}$; $\mathrm{Y}=\mathrm{Yes}$; $\mathrm{D}=\mathrm{disc}$; $\mathrm{M}=$ macula; $\mathrm{ST}=$ superotemporal; $\mathrm{IT}=$ inferotemporal; $\mathrm{SN}=$ superonasal; $\mathrm{F}=$ fibrous $\mathrm{ERM}, \mathrm{FV}=$ fibrovascular; $\mathrm{V}=$ vascular; gr. Edge $=$ growing edge; a Duration $=$ duration of ERM. 
Table 2 Histopathologic and clinical details of the patients of group 2 (vaso-inflammatory diseases with epiretinal membranes)

\begin{tabular}{|c|c|c|c|c|c|c|c|c|c|c|c|c|c|}
\hline \multirow[t]{2}{*}{$S N o$} & \multirow[t]{2}{*}{ Gender } & \multirow{2}{*}{$\begin{array}{c}\text { Age } \\
\text { (years) }\end{array}$} & \multirow[t]{2}{*}{ Eye } & \multirow[t]{2}{*}{ Diagnosis } & \multirow{2}{*}{$\begin{array}{c}\text { Duration }^{\text {a }} \\
\text { (months) }\end{array}$} & \multicolumn{2}{|c|}{ Visual acuity } & \multirow[t]{2}{*}{ Cryo } & \multirow[t]{2}{*}{ Laser } & \multirow{2}{*}{$\begin{array}{l}\text { Location } \\
\text { of ERM }\end{array}$} & \multicolumn{2}{|r|}{ Type of ERM } & \multirow{2}{*}{$\begin{array}{c}\text { Follow-up } \\
\text { (months) }\end{array}$} \\
\hline & & & & & & Pre-op & Post-op & & & & Clinical & Histopath. & \\
\hline 1 & $\mathrm{M}$ & 45 & OD & IVPED & 12 & $\mathrm{HM}$ & CF $1 \mathrm{mt}$ & $\mathrm{N}$ & $\mathrm{N}$ & Macula & FV, Infl & $\mathrm{FV}$, Infl & 4 \\
\hline 2 & M & 52 & OD & IVPED & 6 & $20 / 400$ & $20 / 70$ & $\mathrm{~N}$ & $\mathrm{~N}$ & Macula & F, Infl & F, Infl & 6 \\
\hline 3 & M & 18 & OD & IVPED & 4 & $\mathrm{CF} 1 \mathrm{mt}$ & $20 / 400$ & $\mathrm{~N}$ & $\mathrm{~N}$ & M, IT & FV, Infl & $\mathrm{FV}$, Infl & 3 \\
\hline 4 & M & 46 & OS & IVPED & 5 & $\mathrm{CF} 3 \mathrm{mt}$ & $20 / 80$ & $\mathrm{Y}$ & $\mathrm{N}$ & $\mathrm{M}, \mathrm{ST}, \mathrm{IT}$ & $\mathrm{V}$, Infl & $\mathrm{V}+$ gr. edge, Infl & 12 \\
\hline 5 & M & 32 & OS & IVPED & 11 & $2 \mathrm{mt}$ & $20 / 400$ & $\mathrm{~N}$ & $\mathrm{Y}$ & Macula & F, Infl & F, Infl & 32 \\
\hline 6 & $\mathrm{M}$ & 21 & OD & IVPED & 19 & CF $1 \mathrm{mt}$ & $20 / 25$ & $\mathrm{~N}$ & $\mathrm{~N}$ & $\mathrm{D}, \mathrm{M}, \mathrm{IT}$ & V, Infl & $\mathrm{V}$, Infl & 11 \\
\hline 7 & M & 23 & OD & IVPED & 11 & $20 / 300$ & $20 / 20$ & $\mathrm{Y}$ & $\mathrm{N}$ & $\mathrm{D}, \mathrm{M}, \mathrm{IT}$ & FV, Infl & $\mathrm{FV}$, Infl & 6 \\
\hline 8 & M & 25 & OS & IVPED & 72 & $\mathrm{LP}$ & $20 / 160$ & Y & $\mathrm{Y}$ & $\mathrm{D}, \mathrm{IT}$ & $\mathrm{FV}$ & F, Infl & 34 \\
\hline 9 & M & 35 & OD & IVPED & 10 & LP & LP & $\mathrm{N}$ & $\mathrm{N}$ & $\mathrm{D}, \mathrm{M}, \mathrm{ST}$ & F, Infl & F, Infl & 6 \\
\hline 10 & M & 37 & OS & IVPED & 6 & LP & $\mathrm{HM}$ & $\mathrm{N}$ & $\mathrm{Y}$ & Macula & $\mathrm{F}$ & $\mathrm{F}$ & 35 \\
\hline 11 & M & 34 & OD & IVPED & 2 & LP & $20 / 125$ & $\mathrm{~N}$ & $\mathrm{Y}$ & $\mathrm{D}, \mathrm{M}$ & F, Infl & $\mathrm{FV}$, Infl & 13 \\
\hline 12 & M & 37 & OD & IVPED & 10 & LP & $20 / 25$ & $\mathrm{~N}$ & $\mathrm{~N}$ & Disc & F, Infl & $\mathrm{FV}$, Infl & 6 \\
\hline 13 & M & 30 & OS & IVPED & 8 & $20 / 400$ & $20 / 100$ & $\mathrm{~N}$ & $\mathrm{Y}$ & $\mathrm{D}, \mathrm{ST}$ & $\mathrm{FV}$, Infl & FV, Infl, gr. edge & 6 \\
\hline 14 & M & 36 & OS & IVPED & 48 & $20 / 160$ & $20 / 80$ & $\mathrm{Y}$ & $\mathrm{N}$ & Macula & F, Infl & F, Infl & 4 \\
\hline 15 & M & 22 & OS & IVPED & 13 & $\mathrm{LP}$ & $20 / 80$ & $\mathrm{~N}$ & $\mathrm{~N}$ & $\mathrm{D}, \mathrm{IT}$ & $\mathrm{FV}$, Infl & $\mathrm{V}$, Infl & 7 \\
\hline 16 & M & 28 & OD & IVPED & 2 & $\mathrm{LP}$ & $20 / 100$ & $\mathrm{~N}$ & $\mathrm{Y}$ & $\mathrm{D}, \mathrm{ST}$ & F, Infl & F, Infl & 9 \\
\hline 17 & M & 35 & OS & IVPED & 3 & $\mathrm{CF} 1 \mathrm{mt}$ & $20 / 70$ & $\mathrm{~N}$ & $\mathrm{~N}$ & $\mathrm{M}+\mathrm{D}, \mathrm{ST}$ & F, Infl & F, Infl & 6 \\
\hline 18 & M & 38 & OS & IVPED & 12 & $20 / 100$ & $20 / 40$ & $\mathrm{~N}$ & $\mathrm{~N}$ & Macula & F, Infl & F, Infl & 10 \\
\hline
\end{tabular}

$\mathrm{M}=$ male; $\mathrm{F}=$ female; $\mathrm{OD}=$ right eye; $\mathrm{OS}=$ left eye; $\mathrm{HM}=$ hand movements; $\mathrm{LP}=$ light perception; $\mathrm{CF}=$ counting fingers; $\mathrm{N}=\mathrm{No} ; \mathrm{Y}=$ yes; $\mathrm{D}=$ disc; $\mathrm{M}=$ macula; $\mathrm{ST}=$ superotemporal; $\mathrm{IT}=$ inferotemporal; $\mathrm{F}=$ fibrous $\mathrm{ERM} ; \mathrm{FV}=$ fibrovascular; $\mathrm{V}=$ vascular; Infl = inflammatory; gr. edge = growing edge; IVPED = idiopathic vasculitis of presumed Eales' disease.

${ }^{\mathrm{a}}$ Duration $=$ duration of ERM.

with previous laser/cryotherapy was observed in 13 of $16(81.3 \%)$ in Group I and eight of nine (88.9\%) eyes in Group $2(P=1.0)$.

The distribution of location of membrane in Group 1 $(n=24)$ was as follows: macula - 12 , disc - 13 , above the superotemporal vascular arcade -9 and below the inferotemporal vascular arcade -4 . The distribution of membrane location in group $2(n=18)$ was as follows: macula - 13, disc - 10, below the inferior temporal vascular arcade -6 and above the superotemporal vascular arcade -5 . The membranes were present in more than one location in a given patient because of their extensive nature.

\section{Histologic features}

Predominantly vascular membranes

The active growing edges were seen in two of 24 (8.3\%) specimens in Group 1 and four of $18(22.2 \%)$ in Group 2 $(P=0.375)$. Group 2 ERMs were characterized by the presence of inflammatory cells in addition to being predominantly vascular. Few membranes were associated with extrastromal haemorrhage (one in Group 1 and two in Group 2) (Figure 1b and e).

\section{Predominantly fibrous membranes}

The presence of fibrocellular and collagen components predominated in these membranes with scanty vascular components. Hyalinization was seen in the centre in few specimens in both the groups. The edges of the membranes were devoid of active vascular components. Predominantly fibrous membranes were observed in five of $24(20.8 \%)$ in Group 1 and eight of 18 (44.4\%) in Group $2(P=0.18)$. Inflammatory cells were seen in Group 2 patients although the number of cells per field was less compared to a predominantly vascular membranes of the same group (Figure 1c and f). Membranes in Group 1 were associated with scanty or no inflammatory cellular components.

\section{Fibrovascular membranes}

Fibrovascular membranes were observed in 17 of 24 $(70.8 \%)$ in Group 1 and six of $18(33.3 \%)$ in Group 2 $(P=0.028)$ (Figure 1g). Some membranes showed intraand extracellular pigment deposits (Figure 1h). Inflammatory components were seen scarce in Group 1 and in abundance in Group 2 membranes.

\section{Inflammatory membranes}

Inflammatory type of membranes were observed in none of the specimens in Group 1, but were observed in 17 of $18(94.4 \%)$ in Group $2(P<0.0001)$. The inflammatory component of varying intensities was observed in addition to the above-described three types of membranes in Group 2 (Figure 1c and f). Based on the histological characteristics, mast cells were observed in 
two, macrophages were observed in 10, monocytes in 16, and eosinophils in two specimens each.

\section{Type of membranes vs duration of disease}

The median duration of visual symptoms was 13 months in eye with predominantly vascular membranes, 10 months in predominantly fibrous, and 8 months in fibrovascular membranes. Predominantly vascular type of membranes were associated with longer duration of symptoms, although this did not achieve the statistical significance ( $P=0.25$, Kruskal-Wallis test).

\section{Cellular components of the membranes}

The essential cellular components observed in the epiretinal membranes were fibroblasts, fibrocollagen, glial cells, astrocytes, and myofibroblasts (Figure $2 \mathrm{c}$ and d) in both the groups and were essentially comparable in numbers. The fibrocytes were identified by the ovoid nuclei, innumerable intracytoplasmic filaments, elongated cytoplasmic processes and lack of polarity (Figure 2d). Monocytes were present in ERMs of both the groups, Group 1 membranes had minimal number of monocytes per field and Group 2 membranes had abundant monocytes per field. The inflammatory cells that were present in Group 2 membranes only include macrophages (11 of $18 ; 61.1 \%$ ), eosinophils (two of 18 ; $11.1 \%$ ) and mast cells (two of $18 ; 11.1 \%$ ). Macrophages were identified by the presence of phagic vacuoles and residual bodies (Figure 2e). Eosinophils were identified by the presence of intracytoplasmic granules (Figure 2f). Pigment epithelium was another important cellular component observed in ERMs of both the groups, in 15 of $24(62.5 \%)$ membranes in Group 1 and 11 of $18(61.1 \%)$ membranes in Group $2(P>0.05)$. Fibroblastic transformation of the pigment epithelium was noted in some specimens (Figure $2 \mathrm{~g}$ and $\mathrm{h}$ ). There was no clinically visible breach in the retina in any of the patients. There was no correlation between the presence of RPE and prior laser or cryo therapy $(P>0.05)$.

\section{Discussion}

The aetiopathogenesis of idiopathic retinal vasculitis of presumed Eales' disease is not well understood. Currently, Eales' disease is in essence a diagnosis of exclusion of the diseases that are known to be associated with retinal vasculitis. ${ }^{31-45}$ Epiretinal membranes obtained from the patients with Eales' disease could form a good specimen to study the aetiopathogenesis. ${ }^{7}$ In its proliferative stages, Eales' disease mimics other vasoproliferative disorders like diabetic retinopathy and vascular occlusions. ${ }^{7}$ Very few studies in past have focused on the histologic details and their clinical implications in this disorder. ${ }^{5,7}$ In our study, we tried to address this question and compared with clinically similar group of disorders such as diabetic retinopathy and vascular occlusions.

The location of the ERMs noted in patients of Eales' disease are not significantly different from the other vasoproliferative disorders (23 vs 25 occasions ERMs were observed in the posterior pole in our study). This observation is contrary to the clinical description of peripheral location of the disease in Eales' disease. ${ }^{1-10} \mathrm{We}$ are unsure whether it was because only the severe form of the disease required the surgical intervention or the posterior location of ERMs in Eales' disease is not a rare observation.

Despite the longer duration of the epiretinal membranes in patients with idiopathic vasculitis, the persistence of inflammation at the cellular level was very striking (seven of eight predominantly fibrous membranes had inflammatory cells; Figure 1c and f). Lymphocytes observed predominantly in the membranes obtained from patients of Eales' disease, was suggestive of chronic inflammation. In the past, T-lymphocytes and cell-mediated immune mechanism have been implicated in Eales' disease. ${ }^{5,6}$ Immunophenotyping of the lymphocytes was not conducted in our study. Several immune-mediated diseases including Behcet's disease, sarcoidosis, rhematoid arthritis, Vogt-Koyanagi-Harada, Wegener's granulomatosis, and Crohn's disease causing retinal vasculitis are known to be associated with lymphocytic infiltration of the affected tissues. ${ }^{32-45}$ Since we had excluded all the aforementioned conditions, lymphocytic infiltration in the ERMs was least expected. Our observation supports the hypothesis of triggering of immune mechanism by an unknown antigen in patients of Eales' disease resulting in active perivasculitis and resultant cascade of events observed at different stages of the disease process.

Fibrous and vascular type of membranes predominated in patients with idiopathic vasculitis and fibrovascular membranes in diabetic retinopathy or venous occlusions. ERMs in diabetic retinopathy and venous occlusions are known to follow a sequence of events in their evolution, that is, predominantly vascular followed by fibrovascular and predominantly fibrous membranes. The predominance of fibrous and vascular type of membranes in Eales' disease indicates the selflimiting nature of the disease process. The inflammatory cells, though present in majority of the specimens of both the subgroups, the density of inflammatory cells was far greater in patients of idiopathic vasculitis of presumed Eales' disease. Presumably, inflammatory vaso-occlusion causes retinal ischaemia, leading to vasoproliferation. However, this vasoproliferation subsides once the areas of retinal ischaemia is knocked off by photocoagulation causing fibrosis of the membrane. In contrast, diabetic 

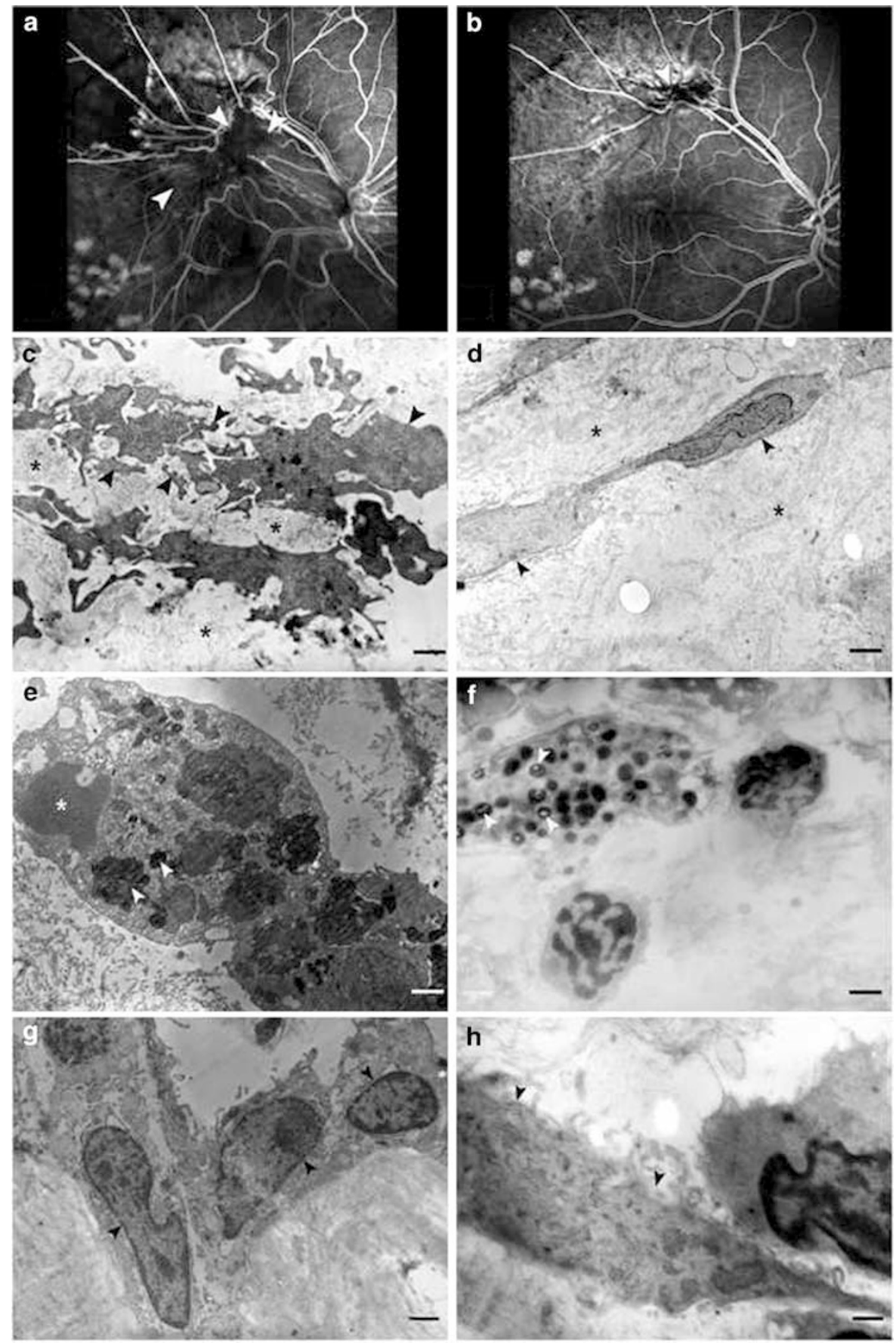

Figure 2 ( $a$ and b) Pre- and postoperative angiograms of the same patient as in Figure 1c and d showing: (a) grossly distorted retinal vasculature (white arrowheads). (b) Recovery of the distortion of the retinal vasculature with good perfusion of the macular area and the area of origin of ERM (white arrowhead). (c-h). Transmission electron photomicrographs from patients of Eales' disease showing: (c). cluster of glial cells (black arrowheads) with interdigitating processes in loosely packed collagen fibrils (black asterisks) $(1 \mathrm{~mm}=300 \mathrm{~nm})$, (d) fibrocyte-like cells (black arrowheads) with cytoplasmic processes and collagen matrix (black asterisks) $(1 \mathrm{~mm}=400 \mathrm{~nm})$, (e) macrophage-like cells with phagic vacuoles (white asterisk) and residual bodies (white arrowheads) $(1 \mathrm{~mm}=400 \mathrm{~nm})$, and $(\mathrm{f})$ eosinophils with characteristic intracytoplasmic granules (white arrowheads) $(1 \mathrm{~mm}=300 \mathrm{~nm}) .(\mathrm{g} \mathrm{and} \mathrm{h})$ Fibroblastic transformation of pigment epithelium (black arrowheads) $(1 \mathrm{~mm}=150 \mathrm{~nm})$.

retinopathy is marked by a lingering process of vasoocclusion causing persistence of vasoproliferation, and hence persistence of fibrovascular membranes. ${ }^{27}$
RPE cells were observed in majority of the specimens in both the groups. The presence of RPE cells in the absence of any clinically visible breaks in the retina is 
interesting. Similar observations have been made earlier by Smiddy et $a l^{19}$ in patients of idiopathic ERMs. These cells possibly migrated through the thinned retina or through a subclinical breach in the retina as suggested by Smiddy et al; alternatively, there could be a transretinal migration of the RPE induced by the vitreous traction as shown by Kono et al. ${ }^{28}$ Several cellular components contribute or participate in the ERM formation in Eales' and other vasoproliferative disorders..$^{22,23,25,28}$ In our study, they include: (a) RPE (as fibroblastic transformation of pigment epithelium) (Figure $2 \mathrm{~g}$ and h),(b) astrocytes indicative of glial contribution (Figure 2c) and (c) macrophages (Figure 2e).

The ERMs of Eales' disease showed a variety of inflammatory cells. Four of the 18 specimens showed presence of mast cells or eosinophils. This is not described often before. This prompts us to consider an allergy or parasitic infestation as a possible aetiology in some patients of idiopathic vasculitis. The presence of eosinophils in patients of Eales' disease was described by Bryselbout et $a l^{46}$ and Renie et al. ${ }^{47}$ The presence of eosinophils and mast cells is indicative of a cell-mediated immune process to an antigen innate to the host. Mycobacterium tuberculosis DNA detected in specimens of ERM from Eales' disease by nested PCR technique by Madhavan $\mathrm{et}^{\mathrm{al}} \mathrm{l}^{7}$ suggests such a process. The use of molecular diagnostic techniques could be useful in understanding the aetiopathogenesis of Eales' disease. ${ }^{48-}$ ${ }^{50}$ We hypothesize that a common protein sequence acts as an antigenic stimulus for an immune cascade that results in perivasculitis characteristic of Eales' disease. Prospective studies are needed in arriving at the common sequence that is responsible for triggering such an immune cascade.

In summary, ERMs form an important specimen to understand the disease process. In this study, the cellular components of ERMs appeared to be an important clue to the aetiology in patients of idiopathic retinal vasculitis. Although we could not find any relevant correlation between the clinical findings and histological features, histological features themselves appeared very significant. The retrospective nature of the study and the stage at which the ERMs obtained, might be the reason for poor correlation. Lack of immunophenotyping of the cellular components and polymerage chain reaction studies of the specimens, is one of the weaknesses of this study. We plan to include them in our future prospective study designs.

\section{Acknowledgements}

We acknowledge Ms Rishitha Nuthethi, Department of Public Health Ophthalmology Services, LV Prasad Eye
Institute, for statistical analysis. This work was supported by Hyderabad Eye Research Foundation.

\section{References}

1 Eales H. Primary retinal hemorrhage in young men. Ophthalmic Rev 1882; 1: 41.

2 Elliot AJ. 30-year observation of patients with Eales' disease. Am J Ophthalmol 1975; 80: 404-408.

3 Keith-lyle T, Wybar K. Retinal vasculitis. Br J Ophthalmol 1961; 45: 778-788.

4 Kimura SJ, Carriker FR, Hogen MJ. Retinal vasculitis with intraocular hemorrhage, classification and results of special studies. Arch Ophthalmol 1956; 56: 361.

5 Das T, Biswas J, Kumar A, Nagpal PN, Namperumalsamy P, Patnaik B et al. Eales' disease. Indian J Ophthalmol 1994; 42(1): 3-18.

6 Biswas J, Sharma T, Gopal L, Madhavan HN, Sulochana KN, Ramakrishnan S. Eales' disease - an update. Surv Ophthalmol 2002; 47(3): 197-214.

7 Madhavan HN, Therese KL, Gunisha P, Jayanthi U, Biswas J. Mycobacterium tuberculosis in epiretinal membrane in Eales' disease. Invest Ophthalmol Vis Sci 2000; 41(3): 822-825.

8 Sulochana KN, Biswas J, Ramakrishnan S. Eales' disease: increased oxidation and peroxidation products of membrane constituents chiefly lipids and decreased antioxidant enzymes and reduced glutathione in vitreous. Curr Eye Res 1999; 19(3): 254-259.

9 Bhooma V, Sulochana KN, Biswas J, Ramakrishnan S. Eales' disease: accumulation of reactive oxygen intermediates and lipid peroxides and decrease of antioxidants causing inflammation, neovascularization and retinal damage. Curr Eye Res 1997; 16: 91-95.

10 Badrinath SS, Gopal L, Sharma T, Parikh S, Shanmugam MP, Bhende P et al. Vitreoschisis in Eales' disease. Pathogenic role and significance in surgery. Retina 1999; 19: 51-54.

11 Ussman JH, Lazarides E, Ryan SJ. Traction retinal detachment. A cell mediated event. Arch Ophthalmol 1981; 99: 869-872.

12 Sramek SJ, Wallow IH, Stevens TS, Nork TH. Immunostaining of preretinal membranes for actin, fibronectin and glial fibrillary acidic protein. Ophthalmology 1989; 96: 835-841.

13 Yamamoto T, Akabane N, Takenchi S. Vitrectomy for diabetic macular edema: the role of posterior vitreous detachment and epimacular membrane. Am J Ophthalmol 2001; 132: 369-377.

14 Barr CC, Michels RG. Idiopathic non vascularized epiretinal membranes in young patients. Report of six cases. Ann Ophthalmol 1982; 14(4): 335-341.

15 Miyao A, Ikeda T, Matsumoto Y, Uchida K, Machida T, Hongo $\mathrm{M}$ et al. Histopathological findings in proliferative membrane formation from a patient with sarcoid uveitis. Jpn J Ophthalmol 1999; 43: 209-212.

16 Grierson I, Mazure A, Hogg P, Hiscott P, Sheridan C, Wong D. Non-vascular vitreoretinopathy: the cells and the cellular basis of contraction. Eye 1996; 10: 671-684.

17 Matsumoto BT, Adelberg DA, Delpriore LV. Transretinal membrane formation in diffuse unilateral subacute neuroretinitis. Retina 1995; 15: 146-149.

18 Mazure A, Grieson I. In vitro studies of the contractility of cell types involved in proliferative vitreoretinopathy. Invest Ophthalmol Vis Sci 1992; 33: 3407-3416. 
19 Smiddy WE, Maguire AM, Green WR, Michels RG, de la Cruz Z, Enger $\mathrm{C}$ et al. Idiopathic epiretinal membranes. Ultrastructural characteristics and clinicopathologic correlation. Ophthalmology 1989; 96: 811-820.

20 Shinoda K, Hirakata A, Hida T, Yamaguchi Y, Fukuda M, Maekawa $\mathrm{S}$ et al. Ultrastructural and immunohistochemical findings in five patients with vitreomacular traction syndrome. Retina 2000; 20: 289-293.

21 Carney Md, Jampol LM. Epiretinal membranes in sickle cell retinopathy. Arch Ophthalmol 1987; 105: 214-217.

22 Kampik A, Green WR, Michels RG, Nase PK. Ultrastructural features of progressive idiopathic epiretinal membrane removed by vitreous surgery. Am J Ophthalmol 1980; 90: 797-809.

23 Kenyon KR, Michels RG. Ultrastructure of epiretinal membrane removed by parsplana vitreo-retinal surgery. $A m$ J Ophthalmol 1977; 83: 815-823.

24 Morino I, Hiscott P, Mckechnie N, Grierson I. Variation in epiretinal membrane components with clinical duration of the proliferative tissue. Br J Ophthalmol 1990; 74: 393-399.

25 Jiang DY, Hiscott PS, Grierson I, Mc leod D. Growth and contractility of cells from fibrocellular epiretinal membranes in primary tissue culture. $\mathrm{Br}$ J Ophthalmol 1988; 72: 116-126.

26 Bouzas EA, Karadimas P, Alexandrou A, PanagoPoulos I. Epiretinal membrane in association with Takayasu disease. Acta Ophthalmol Scand 1999; 77: 483-484.

27 Das A, McGuire PG, Eriqat C, Ober RR, deJuan Jr E, Williams GA et al. Human diabetic membranes contain high levels of urokinase and metalloproteinase enzymes. Invest Ophthalmol Vis Sci 1999; 40(3): 809-813.

28 Kono I, Kohno T, Inomata H. Epiretinal membrane formation. Light and electron microscopic study in an experimental rabbit model. Arch Ophthalmol 1995; 113: 359-363.

29 Hunt RC, Pakalnis VA, Choudhury P, Black EP. Cytokines and serum cause $L_{2} B_{1}$ integrin-mediated contraction of collagen gels by cultured retinal pigment epithelial cells. Invest Ophthalmol Vis Sci 1994; 35: 955-963.

30 Desai UR, Blinder KJ, Dennehy PJ. Vitrectomy and juvenile epiretinal membrane. Ophthalmic Surg Lasers 1996; 27: 137-139.

31 Abu El-Asrar AM, Al-Kharashi SA. Full panretinal photocoagulation and early vitrectomy improve prognosis of retinal vasculitis associated with tuberculoprotein hypersensitivity (Eales' disease). Br J Ophthalmol 2002; 86: 1248-1251.

32 Charteris DG, Champ C, Rosenthal AR, Lightman SL. Bahcet's disease: activated T lymphocytes in retinal perivasculitis. Br J Ophthalmol 1992; 76: 499-501.

33 George RK, Walton C, Whitcup SM, Nussenblatt RB. Primary retinal vasculitis: systemic associations and diagnostic evaluation. Ophthalmology 1996; 103: 384-389.
34 Farmer SG, Kinyoun JL, Nelson JL, Wener MH. Retinal vasculitis associated with antibodies to Sjogren's syndrome A antigen. Am J Ophthalmol 1985; 100: 814-821.

35 Ruby AJ, Jampol LM. Crohn's disease and retinal vascular disease. Am J Ophthalmol 1990; 110: 349-353.

36 Chang TS, Aylward GW, Davis JL, Mieler WF, Oliver GL, Maberley AL et al. Idiopathic retinal vasculitis, aneurysms and neuroretinitis. Ophthalmology 1995; 102: 1089-1097.

37 James DG, Graham E, Hamblin A. Immunology of multisystem ocular disease. Surv Ophthalmol 1985; 30: 155-167.

38 Patrinely JR, Green WR, Randolph ME. Retinal phlebitis with chorioretinal emboli. Am J Ophthalmol 1982; 94: 49-57.

39 Topilow HW, Nussbaum JJ, Freeman M, Dickersin GR, Szyfelbein W. Bilateral acute retinal necrosis. Clinical and ultrastructural study. Arch Ophthalmol 1982; 100: 1901-1908.

40 Stanford MR, Graham E, Kasp E, Sanders MD, Dumonde DC. A longitudinal study of clinical and immunological findings in 52 patients with relapsing retinal vasculitis. $\mathrm{Br} \mathrm{J}$ Ophthalmol 1988; 72: 442-447.

41 Isashiki M, Koide H, Yamashita T, Ohba N. Acute posterior multifocal placoid pigment epitheliopathy associated with diffuse retinal vasculitis and late hemorrhagic macular detachment. Br J Ophthalmol 1986; 70: 255-259.

42 Van Meurs JC, Lightman S, de Waard PW, Baarsma GS, van Suijlekom-Smit LW, van de Merwe JP et al. Retinal vasculitis occurring with common variable immuno deficiency syndrome. Am J Ophthalmol 2000; 129: 269-270.

43 Snyder DA, Tessler HH. Vogt-Koyanagi-Harada syndrome. Am J Ophthalmol 1980; 90: 69-75.

44 Bullen CL, Liesegang TJ, Mc donald TJ, de Reme RA. Ocular complications of Wagner's granulomatosis. Ophthalmology 1983; 90: 279-290.

45 Matsuo T, Masuda I, Matsuo N. Geographic choroiditis and retinal vasculitis in rheumatoid arthritis. Jpn J Ophthalmol 1998; 42: 51-55.

46 Bryselbout E, Turut P, Malthieu D, Milazzo S. Eales' syndrome and hypereosinophilia. Bull Soc Ophthalmol Fr 1989; 89: 1421-1424.

47 Renie WA, Murphy RP, Anderson KC, Lippman SM, McKusick VA, Proctor LR et al. The evaluation of patients with Eales' disease. Retina 1983; 3: 243-248.

48 Patrinely JR, Green WR, Randolph ME. Retinal phlebitis with chorioretinal emboli. Am J Ophthalmol 1982; 94: 49-57.

49 Whittle RM, Wallace GR, Whiston RA, Dumonde DC, Stanford MR. Human antiretinal antibodies in toxoplasma retinochoroiditis. Br J Ophthalmol 1998; 82: 1017-1021.

50 Mikkila HO, Seppala IJT, Viljanen MK, Peltomaa MP, Karma A. The expanding clinical spectrum of ocular lyme borreliosis. Ophthalmology 2000; 107: 581-587. 